\title{
Symposium on Ludwig Von Mises: Nation State and Economy
}

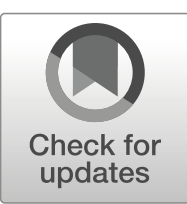

\author{
Peter J. Boettke ${ }^{1}$
}

Published online: 27 June 2019

(C) Springer Science+Business Media, LLC, part of Springer Nature 2019

\section{JEL codes B53-Austrian Economics}

Ludwig von Mises published Nation, State and Economy in 1919, on the heels of WWI- of which he participated as a solider. Already an established monetary economist after the publication of his Theory of Money and Credit in 1912, Mises was also well known as a leading representative of liberalism. An ardent defender of free trade and free enterprise, as well as sound money and fiscal restraint, Mises sought to address the question of the restoration of economic policy from wartime emergency to a time of peace, and hopefully a resurgent prosperity throughout Europe. War, it has been said, is the health of the state, but what Mises was concerned with was the health and wellbeing of society and the freedom of the individuals living within the aftermath of war. Nation, State and Economy is a book full of fascinating insights that, as our contributors demonstrate, still speak to us today.

The Society for Development of Austrian Economics in November 2018 held a panel featuring Christopher Coyne, Richard Ebeling and Benjamin Powell who each addressed fundamental insights from Mises's great work.

Publisher's note Springer Nature remains neutral with regard to jurisdictional claims in published maps and institutional affiliations.

Peter J. Boettke

pboettke@gmu.edu

1 George Mason University, Fairfax, VA, USA 